\title{
Telur Parasit Nematoda Usus pada Pemukiman Kurang Sehat di Kota Pekanbaru
}

\author{
The Intestinal Nematode Parasite Eggs at Less Healthy Settlements In \\ Pekanbaru
}

\author{
Denai Wahyuni, Arniwita, Fachriani Putri, Erdinal
}

\author{
Program Studi IImu Kesehatan Masyarakat STIKes Hang Tuah Pekanbaru
}

\begin{abstract}
ABSTRAK
Kondisi lingkungan perumahan yang kurang mendukung seperti drainase dengan kondisi kurang memenuhi syarat serta masyarakat kurang menyadari adanya hubungan antara kekumuhan tempat tinggal dan epidemi penyakit, akan menimbulkan salah satu dampak pada masyarakat yaitu penyakit infeksi parasit nematoda usus. Tujuan penelitian ini untuk mengetahui kondisi drainase, jenis parasit nematoda usus, kepadatan dan frekuensi kehadiran telur parasit nematoda usus pada pemukiman kurang sehat di Kota Pekanbaru. Sampel diambil dengan teknik Purposif Sampling. Dipilih tiga level pemukiman yang termasuk kriteria pemukiman kurang sehat. Dari ketiga daerah pemukiman di atas dipilih lingkungan kelompok rumah yang punya drainase permanen, semi permanen dan drainase konvensional. Masing-masing kelompok drainase diambil 20 rumah yang dijadikan sebagai sampel. Untuk membandingkan perbedaan kepadatan telur dari jenis-jenis nematoda parasit usus manusia yang ditemukan pada tanah antar lokasi pemukiman dilakukan dengan uji Kruskall-Wallis. Ditemukan telur dari dari 2 jenis parasit nematoda usus di tanah lingkungan pemukiman kurang sehat yaitu A. lumbricoides, T. trichiura pada semua lokasi drainase. Berdasarkan analisis statistik Kruskall Wallis ternyata kepadatan telur A.lumbricoides antar lokasi berbeda nyata, sedangkan kepadatan telur T. trichiura antar lokasi tidak berbeda nyata. Frekuensi kehadiran telur A. lumbricoides lebih tinggi dibandingkan dengan telur T. trichiura. Frekuensi kehadiran dari telur tersebut berturut-turut adalah 66,67 \% dan 53,33\%.
\end{abstract}

Kata Kunci : Telur Parasit Nematoda Usus, Pemukiman Kurang Sehat, Pekanbaru

\begin{abstract}
ABSTRACK
Unfavorable conditions of housing environmental such as unqualified drainage and the lack of awareness of the peoples in recognizing the relationship between the squalor rate of housing and epidemic disease, will cause one of the impacts on the community that is called as intestinal nematode parasite infection. The purpose of this study is determining the type, density and frequency of the presence of intestinal nematode parasite eggs on the less healthy housing in Pekanbaru. Samples were taken with the technique of "purposive sampling". It was selected three levels of housing that could be classified as less healthy settlement criteria. Of the three settlement areas, it was selected three types of neighborhood group homes that have the permanent, semi permanent and conventional drainage. For each group, it was taken 20 houses as a sample. To compare the differences of the density of nematode parasites eggs from human intestinal found in the soil among the location of each group of housing, it was conducted the Kruskall-Wallis test. It was found the egg of two species of intestinal nematode parasites in soil of less healthy neighborhoods such as A. Lumbricoides and T. trichiura all over the drainage locations. Based on Kruskall Wallis statistical analysis, A.lumbricoides egg density was significantly different among sites, whereas the density T. trichiura eggs was not significantly different among sites. The presence frequency of A. Lumbricoides eggs was higher than T. trichiura. The presense frequency of A. Lumbricoides and T. Trichiura eggs are $66.67 \%$ and $53.33 \%$.
\end{abstract}

Key words: Intestinal Nematode Parasite Eggs, Less Healthy Settlement, Pekanbaru

\section{PENDAHULUAN}

Kesengsaraan suatu lingkungan pemukiman/ perumahan dapat disebabkan oleh tingkat perilaku penduduk yang tidak higienis dan disamping itu tidak adanya sarana dan prasarana lingkungan yang mendukung sehingga berdampak pada kesehatan masyarakat pemukiman itu. Pengadaan rumahrumah sederhana dan rumah liar yang dibangun oleh sektor masyarakat berpenghasilan rendah jumlahnya relatif banyak, tetapi dengan kualitas dibawah standar pemerintah, ada yang berlokasi di pinggir-pinggir rel kereta api, pinggir sungai bahkan di sekitar tempattempat pembuangan sampah. Pemukiman di lokasi seperti ini biasanya kurang sehat sehingga akan menimbulkan masalah lingkungan (Panudju, 1999).

Salah satu gejala yang terjadi pada lingkungan pemukiman yang kurang sehat adalah penyakit infeksi parasit nematoda usus. Brown (1983), menyatakan bahwa penyakit infeksi parasit nematoda usus banyak ditemui di daerah kumuh yang padat penduduknya dan merupakan dampak atau 
masalah kesehatan. Akibat dari penyakit infeksi parasit nematoda usus banyak menyangkut masalah kualitas hidup seperti yang diungkapkan oleh Widjaya (2001), infeksi ini telah menyebabkan; manusia kehilangan karbohidrat, protein dan darah yang cukup besar, menurunkan kemampuan fisik dan ketajaman fikiran anak-anak, menurunkan produktivitas kerja orang dewasa dan mengurangi daya tahan tubuh sehingga lebih rentan terhadap serangan penyakit-penyakit lainnya. Kerugian kerugian tersebut diperkirakan setara dengan kehilangan $47.103 .615 \mathrm{~kg}$ beras atau setahun. Diperkirakan kehilangan darah sebanyak 90 juta liter pada manusia semata-mata hanya infeksi oleh Ancylostoma duodenale dan Trichuris tichiura.

Beberapa daerah pemukiman di Kota Pekanbaru yang cukup padat penduduknya dan kurang memenuhi syarat kesehatan, antara lain terletak di Kelurahan Sri Meranti Kec. Rumbai, Kelurahan Meranti Pandak Kec. Rumbai Pesisir dan di Kelurahan Sukaramai Kecamatan Pekanbaru Kota. Jumlah penduduknya padat pada umumnya adalah pendatang atau perantau. Kondisi lingkungan perumahan yang kurang memenuhi syarat serta masyarakat kurang menyadari adanya hubungan antara kekumuhan tempat tinggal dan epidemi penyakit.

Berdasarkan hal tersebut di atas dalam rangka penyehatan lingkungan pemukiman yang kurang sehat, maka dilakukanlah penelitian dengan tujuan untuk mengetahui kondisi drainase, jenis parasit nematoda usus, kepadatan dan frekuensi kehadiran telur parasit nematoda usus pada lingkungan perumahan kurang sehat di Kota Pekanbaru.

\section{METODE PENELITIAN}

Bahan yang digunakan dalam penelitian $\mathrm{ZnSO}_{4}$ dan aquades, sedangkan alat yang digunakan adalah timbangan Ohaus, mikroskop lengkap, sentrifuge, lemari es, cool box, objek glass dan cover glass, tabung reaksi berukuran $10 \mathrm{ml}$, sarung tangan.

Populasi dalam penelitian ini adalah masyarakat pemukiman kurang sehat di Kota Pekanbaru. Sampel diambil dengan teknik "Purposif Sampling". Dipilih tiga pemukiman yang termasuk kriteria pemukiman kurang sehat yaitu; Kelurahan Sri Meranti Kec. Rumbai Pesisir, Kelurahan Sukaramai Kec. Pekanbaru Kota dan Kelurahan Meranti Pandak Kec. Rumbai Pesisir. Dari ketiga daerah pemukiman di atas dipilih lingkungan kelompok rumah yang punya drainase permanen, semi permanen dan drainase konvensional, yang dipilih sebagai kelompok drainase permanen adalah Kelurahan Sukaramai Kec. Pekanbaru Kota, sebagai kelompok drainase semi permanen adalah Kelurahan Sri Meranti Kec. Rumbai dan sebagai kelompok drainase konvensional dipilih setara dengan Rp.94.207.203.000 (\$.13.084.337) kurang mendukung seperti drainase dengan kondisi

Kelurahan Meranti Pandak Kec. Rumbai Pesisir. Masing-masing kelompok drainase diambil 20 rumah yang dijadikan sebagai sampel.

Sebelum pengambilan sampel dihubungi Kepala Keluarga (KK) yang terpilih sebagai sampel. Pada KK yang terpilih sebagai sampel diambil satu sampel tanah di lingkungan perumahan sebanyak dua sendok makan. Tanah yang diambil diduga positif mengandung telur parasit nematoda (Margono 1996). Sampel tanah yang diambil dari lapangan di periksa di Laboratorium dengan menggunakan metoda sentrifusir dan pengapungan (Ismit et al., 1981). Telur dari jenisjenis nematoda parasit usus manusia yang terdapat pada tanah permukaan pemukiman disajikan dalam bentuk tabel, meliputi :

1. Telur dari jenis-jenis nematoda parasit usus manusia yang terdapat pada tanah permukaan.

2. Kepadatan telur dari jenis-jenis nematoda parasit usus manusia dapat dilakukan per 2 gram tanah. Untuk mencari kepadatan dipakai rumus :

$$
\text { Kepadatan }=\frac{\text { Jumlah telur dari satu jenis }}{2 \text { gram tanah }}
$$

Jumlah sampel ditemukan

$$
\mathrm{FK}=\frac{\text { suatu jenis telur nematoda }}{\text { Jumlah seluruh sampel }} \times 100 \%
$$

FK = Frekuensi kehadiran (Michael, 1994).

Untuk membandingkan perbedaan kepadatan telur dari jenis-jenis nematoda parasit usus manusia yang ditemukan pada tanah antar lokasi pemukiman dilakukan dengan uji Kruskall-Wallis (Sudrajad, 1985)

\section{HASIL}

\section{Kondisi Drainase Lingkungan Pemukiman}

Kondisi drainase lingkungan pemukiman kurang sehat di Kota Pekanbaru dapat dibedakan dari tiga bentuk drainase, atas sistem rancangan konstruksi, yang terdiri dari sistem drainase permanen, semi permanen, dan sistem drainase konvensional. Kondisi air buangan dalam drainase dibagi atas dua kelompok yaitu: kondisi drainase dengan air tergenang dan tidak tergenang (lihat tabel 1).

Tabel 1.

Drainase di Lingkungan Pemukiman Kurang Sehat

\begin{tabular}{|c|c|c|c|c|c|}
\hline \multirow{2}{*}{$\begin{array}{c}\text { Sistem } \\
\text { drainase } \\
\text { lingk. } \\
\text { Pemukiman }\end{array}$} & \multirow{2}{*}{$\begin{array}{l}\text { Drai- } \\
\text { nase } \\
\text { perm } \\
\text { anen }\end{array}$} & \multirow{2}{*}{$\begin{array}{l}\text { Drainase } \\
\text { semi per- } \\
\text { manen }\end{array}$} & \multirow{2}{*}{$\begin{array}{c}\text { Drainase } \\
\text { konven- } \\
\text { sional }\end{array}$} & \multicolumn{2}{|c|}{ Total } \\
\hline & & & & $\begin{array}{l}\text { jum } \\
\text {-lah }\end{array}$ & $\%$ \\
\hline Tergenang & 15 & 14 & 17 & 46 & 76,67 \\
\hline $\begin{array}{l}\text { Tdk } \\
\text { tergenang }\end{array}$ & 5 & 6 & 3 & 14 & 23,33 \\
\hline Total & 20 & 20 & 20 & 60 & 100 \\
\hline
\end{tabular}
di Kota Pekanbaru

Jurnal Kesehatan Komunitas, Vol. 1, No. 4, Mei

Page 189 
Dari tiga jenis pemukiman kurang sehat di kota Pekanbaru, diketahui bahwa dari 60 sampel rumah terdapat $46 \quad(76,67 \%)$ rumah mempunyai kondisi drainase yang tergenang, sedangkan 14 $(23,33 \%)$ rumah punya kondisi drainase yang tidak tergenang.

\section{Jenis Parasit Nematoda Usus}

Dari hasil pemeriksaan sampel pada tanah lingkungan pemukiman kurang sehat di Kota Pekanbaru didapatkan telur dari dua jenis parasit nematoda usus yaitu: Ascaris lumbricoides dan Trichiura trichiura.

\section{Kepadatan Telur Parasit Nematoda Usus}

Kepadatan telur parasit nematoda usus pada lingkungan masing-masing lokasi pemukiman kurang sehat di Kota Pekanbaru dapat dilihat pada Tabel 2:

Tabel 2

Kepadatan \& Frekuensi Kehadiran Masing-Masing Jenis Telur Parasit Nematoda Usus yang Didapatkan Pada Permukaan Tanah di Pemukiman Kurang Sehat di Kota Pekanbaru

\begin{tabular}{lccccc}
\hline \multicolumn{1}{c}{$\begin{array}{c}\text { Lokasi } \\
\text { lingkungan }\end{array}$} & $\mathrm{n}$ & \multicolumn{2}{c}{ A. lumbricoides } & \multicolumn{2}{c}{ T. trichiura } \\
\cline { 2 - 6 } & & $\mathrm{K}$ & $\mathrm{F} . \mathrm{K}$ & $\mathrm{K}$ & $\mathrm{F} . \mathrm{K}$ \\
\hline $\begin{array}{l}\text { Drainase } \\
\text { permanen }\end{array}$ & 20 & 4.1 & 60 & 1,05 & 40 \\
$\begin{array}{l}\text { Drainase semi } \\
\text { permanen }\end{array}$ & 20 & 7,3 & 65 & 2,25 & 55 \\
$\begin{array}{l}\text { Drainase } \\
\text { konvensional }\end{array}$ & 20 & 10,7 & 75 & 3,3 & 65 \\
Rata-rata & & 7,37 & 66,67 & 2,2 & 53,33 \\
\hline
\end{tabular}

$\begin{array}{lll}\text { Ket: } & \mathrm{K} & =\text { Kepadatan (butir/2 g tanah) } \\ & \text { FK } & =\text { Frekuensi Kehadiran (\%) }\end{array}$

Kepadatan telur parasit nematoda tertinggi adalah $A$. lumbricoides kemudian diikuti oleh $T$. trichiura. Kepadatan rata-rata dari telur tersebut berturut-turut 7,37 butir/ $2 \mathrm{~g}$ tanah dan 2,2 butir/ $2 \mathrm{~g}$ tanah. Kepadatan telur A. lumbricoides disetiap lokasi bervariasi, lokasi drainase permanen rata-rata 4,1 butir/ $2 \mathrm{~g}$ tanah, lokasi drainase semi permanen 7,3 butir/ $2 \mathrm{~g}$ tanah dan pada lokasi drainase konvensional 10,7 butir/ $2 \mathrm{~g}$ tanah. Berdasarkan analisis statistik Kruskall Wallis ternyata kepadatan telur A. lumbricoides antar lokasi berbeda nyata.

\section{Frekuensi Kehadiran Telur Parasit Nematoda Usus}

Frekuensi Kehadiran Telur Parasit Nematoda Usus dapat dilihat pada tabel 2 . Frekuensi kehadiran telur cacing $A$. lumbricoides lebih tinggi dibandingkan dengan telur nematoda usus T. trichiura. Frekuensi kehadiran dari telur tersebut berturut-turut adalah $60 \%$, $65 \%$ dan $75 \%$. Tingginya frekuensi kehadiran telur parasit nematoda $A$. lumbricoides dibandingkan dengan $T$. trichiura karena banyaknya orang yang terinfeksi telur A. lumbricoides dibandingkan dengan T. trichiura.

\section{PEMBAHASAN}

\section{Kondisi Drainase Lingkungan Pemukiman}

Dari pengamatan kondisi drainase di lapangan, aliran air dalam drainase tidak lancar dan selalu tergenang. Hal ini disebabkan karena salurannya kecil dan tidak punya kemiringan yang cukup hingga tidak mampu menampung semua air buangan rumah tangga dan air hujan.

Suripin (2004), berpendapat pada beberapa kasus, saluran yang tidak mempunyai kemiringan yang cukup, akan mengakibatkan air tidak lancar dan terjadi genangan dalam saluran setelah terjadi hujan. Kondisi air yang tergenang disebabkan tidak terjadinya kecepatan aliran karena kurangnya tingkat kemiringan saluran. Genangan air menyebabkan lingkungan menjadi kotor dan jorok, dan menyebarkan mikroorganisme penyakit dan telur parasit nematoda usus, sehingga dapat menurunkan kualitas lingkungan dan kesehatan masyarakat.

Selanjutnya Slamet (2002), menambahkan bahwa sarana drainase merupakan infrastruktur dasar yang sangat diperlukan dalam lingkungan pemukiman. Tanpa adanya sarana drainase yang baik dan lancar serta memadai, akan mengakibatkan kondisi lingkungan tidak stabil, sering terjadi banjir dan sampah akan membusuk. Bilamana drainase suatu lingkungan tidak lancar sewaktu turun hujan akan selalu ada genangan air hingga kondisi tanah jadi lembab. Kondisi ini merupakan tempat berkembangnya berbagai vektor penyakit yang menular seperti diare, demam berdarah, malaria, kecacingan, disentri dan lain-lain.

\section{Kepadatan Telur Parasit Nematoda Usus}

Tingginya kepadatan telur A. lumbricoides pada lokasi drainase konvensional ini mungkin disebabkan karena tingkat reinfeksi pada penderita yang tinggi dari $A$. lumbricoides dan pencemaran tanah oleh tinja. Di daerah ini sebagian penduduk tidak mempunyai jamban keluarga sehingga mereka terutama anak-anak berdefekasi di tanah perumahan dan diselokan. Hal ini mengakibatkan pada waktu turun hujan tinja yang terdapat di tanah akan menyebar ke sekeliling rumah karena drainase yang sangat sederhana dan tidak mampu menampung limbah rumah tangga serta air hujan, ditambah kebiasaan dari masyarakat buang sampah di lingkungan. Pencemaran tanah dengan tinja manusia di daerah yang kebersihannya kurang baik akan memudahkan terjadinya infeksi parasit nematoda usus (Ismit, 1981). Faktor pendukung lain yang meyebabkan tingginya tingkat kepadatan telur parasit nematoda $A$. lumbricoides adalah karena kondisi tanah yang lembab dan sedikit berlumpur ditambah keadaan rumah 
kebanyakan rumah panggung yang lembab dan berlumpur. Sanitasi lingkungan yang buruk seperti kurangnya pemakaian jamban keluarga serta tempat pemukiman yang padat dan kotor akan menimbulkan pencemaran tanah oleh tinja di sekitar halaman rumah, di bawah pohon dan tempat mencuci. Dari penelitian sebelumnya oleh Wahyuni (2003), di Kelurahan Meranti Pandak Kecamatan Rumbai Kota Pekanbaru didapatkan kepadatan rata-rata telur A. lumbricoides adalah $6,06 \mathrm{butir} / 2 \mathrm{~g}$ tanah yang menunjukkan tingkat kepadatan yang lebih tinggi. Begitu juga jika dibandingkan dengan penelitian yang dilakukan oleh Zoebar (2005), di Kelurahan Meranti Pandak Kecamatan Rumbai Pesisir yang menunjukkan kepadatan rata-rata telur A. lumbricoides sebesar 5,4 butir/ $2 \mathrm{~g}$ tanah.

Kepadatan telur terendah terdapat pada tanah lokasi drainase permanen dengan rata-rata 4,1 butir/ 2 $\mathrm{g}$ tanah. Hal ini disebabkan karena sarana lingkungan sudah sedikit baik, telah adanya beberapa rumah yang punya jamban keluarga dan sebagian rumah sudah punya drainase yang permanen. Tapi walaupun kondisi sudah sedikit lebih baik, kondisi drainase sebagian sudah permanen tidak cukup menurunkan prefalensi cacing Ascaris maupun infeksi cacing lainnya, karena kondisi drainase yang tidak lancar yang dipenuhi oleh sampah. Kebiasaan dari sebagian masyarakat terutama anak-anak yang buang tinja di saluran akan menjadi penyebab berkembangnya mikroorganisme, vektor yang menyebabkan penyakit perut. Kondisi saluran yang tidak lancar ini akan mengakibatkan air tergenang di sekeliling rumah dan menyebarkan mikroorganisme penyakit dan telur parasit nematoda usus. Hal ini akan menyebarkan penyakit parasit nematoda ini pada orang lain. Disamping itu tingkat pendidikan masyarakat yang masih rendah ikut berperan terhadap munculnya telur $A$. lumbricoides ini.

Kepadatan rata-rata telur T. trichiura di tanah pemukiman kurang sehat di Kota Pekanbaru adalah 2,2 butir/ 2 g tanah. Pada lokasi drainase permanen didapatkan rata-rata telur $T$. trichiura 1,05 butir/ $2 \mathrm{~g}$ tanah, lokasi drainase semi permanen rata-rata 2,25 butir/ $2 \mathrm{~g}$ tanah sedangkan pada lokasi drainase konvensional didapatkan rata-rata 3,3 butir/ $2 \mathrm{~g}$ tanah. Berdasarkan hasil analisis statistik uji Kruskall Wallis ternyata kepadatan telur ditiap lokasi tidak berbeda nyata.

Rendahnya kepadatan telur $T$. trichiura dibandingkan dengan telur A. lumbricoides yang ditemukan di daerah pemukiman kurang sehat di Kota Pekanbaru mungkin disebabkan karena sedikit penduduk yang membuang kotoran yang diparasiti oleh nematoda $T$. trichiura. Disamping itu T. trichiura betina diperkirakan hanya mampu bertelur setiap hari antara 3.000-10.000 butir. Jumlah ini jauh sedikit dari telur yang dihasilkan oleh A.lumbricoides betina dewasa yang bertelur antara 100.000 - 200.000 butir setiap hari (Gandahusada, et al., 2.000). Zit (1999) menjelaskan bahwa telur $T$. trichiura mempunyai sifat resistensi atau ketahanan yang hampir sama dengan $A$. lumbricoides dan mampu bertelur sebanyak 3.00010.000 butir dalam sehari dan didukung oleh telur yang berlapis dua dan masa inkubasi 20-40 hari.

Hasil penelitian ini sedikit lebih tinggi bila dibandingkan dengan penelitian Wahyuni (2003) di Kelurahan Meranti Pandak Kec. Rumbai Kota Pekanbaru dan penelitian Zoebar (2005) di Kelurahan Meranti Pandak Kec. Rumbai Kota Pekanbaru yang menemukan kepadatan rata-rata telur $T$. trichiura masing-masingnya 1,93 butir/ $2 \mathrm{~g}$ tanah dan 2,03 butir/ $2 \mathrm{~g}$ tanah.

\section{KESIMPULAN}

Sebagian besar rumah di lingkungan pemukiman kurang sehat Kota Pekanbaru mempuyai kondisi drainase yang tergenang dan pada semua lokasi drainase ditemukan 2 jenis telur parasit nematoda usus yaitu A. Lumbricoides dan T. Trichiura. Parasit nematoda usus paling banyak di temukan pada lokasi drainase kovensional. Kepadatan dan frekuensi kehadiran telur parasit nematoda usus tertinggi adalah jenis $A$. lumbricoides

\section{SARAN}

1. Memberikan penyuluhan kepada masyarakat pemukiman perkotaan tentang pengelolaan lingkungan pemukiman untuk meningkatkan kesejahteraan masyarakat dan dampak kesehatan lingkungan dari pemukiman kurang sehat kepada masyarakat, bila sarana dan prasarana kurang memadai serta perilaku masyarakat yang tidak higienis, mengakibatkan lingkungan yang tidak bersih, serta akan menjadi sarang atau tempat berkembang biaknya agen serta berbagai vektor penyakit.

2. Disarankan kepada pengambil keputusan untuk memberikan/menekankan kepada masyarakat dalam perencanaan dan perancangan sistim drainase pada suatu kawasan lingkungan pemukiman agar tidak dilakukan perencanaan dalam jangka pendek, tetapi dapat dilakukan perencanaan dengan jangka panjang yang menyeluruh dan berkelanjutan sehingga drainase mampu menampung semua kapasitas air buangan rumah tangga maupun buangan air hujan dengan baik, sehingga banjir yang merupakan tempat berkembangnya berbagai agen dan berbagai vektor penyakit menular maupun tidak menular dapat diatasi. 


\section{DAFTAR PUSTAKA}

Brown, H.W. 1983. Dasar parasitologi klinis. Terjemahan B. Rukmono, Gramedia. Jakarta.

Ismid., S.S. Margono., S. Anggraini., M. Harum., R. Rasad., R. Rochida dan B.Rukmono. 1981. Dampak pengobatan infeksi cacing usus terhadap pencemaran tanah dengan telur cacing $A$ lumbricoides. Dalam Seminar Parasitologi ke III. Jakarta.

Margono, S.S. 1996. Pemeriksaan tanah, debu, usap jari dan kotoran kuku terhadap telur $A$. Lubricoides. Majalah Kedokteran Indonesia. Vol 46, No 11. Hal 621-626.

Panudju, B. 1999. Pengadaan perumahan kota dengan peran serta masyarakat berpenghasilan rendah.,kerja sama Yayasan Adikarya IKAPI dengan The Ford Foundation. Penerbit Alumni Bandung.

Slamet.J.S. 2002. Kesehatan Lingkungan,Gajah Mada University Press. Yogyakarta.
Sudrajad, M. 1985. Statistika Non Parametrik. Armico. Bandung.

Suripin. 2004. Sistem Drainase Perkotaan yang Berkelanjutan.Penerbit ANDI Yogyakarta

Wahyuni, D. 2003. Parasit nematoda usus manusia pada penduduk kelurahan meranti pandak kecamatan rumbai kota Pekanbaru. Thesis Fakultas Pasca Sarjana Universitas Andalas, Padang.

Widjaya, D.P. 2001. Kecacingan dan kualitas sumber daya manusia (SDM). Majalah Kedokteran Udayana. Vol 32. No. 32. Hal: 215-221.

Zit, Z. 1999. Kontaminasi telur nematoda usus di Sungai Musi Palembang. Majalah Kedokteran Sriwidjaya. Th 31. No 4. Hal : 9-15.

Zoebar, Y. 2005. Dampak Lingkungan Perumahan Masyarakat Berpenghasilan Rendah Terhadap Perkembangan Parasit Nematoda Usus di Kelurahan Meranti Pandak Kecamatan Rumbai Pesisir Kota Pekanbaru 